\title{
FOREIGN LANGUAGES' INFLUENCE ON ALBANIAN POLICE LEXICON
}

\author{
Shemsi Haziri \\ https://orcid.org/0000-0002-7491-9664 \\ shemsi.haziri@kosovopolice.com \\ University of Prishtina "Hasan Prishtina", Kosovo
}

Received August 6, 2020; Revised September 2, 2020; Accepted October 1, 2020

\begin{abstract}
In this study we attempted to thoroughly explain influences of foreign languages on police lexicon in Albanian language, with special focus on the influence of Serbian and English language in Kosovo, as well as the influence of Italian and English language in Albania. Influence of Serbian language only on police lexicon in Kosovo has been created due to historic circumstances of development of police activities under specific conditions. The impact of Serbian language on police lexicon in Albanian language in Kosovo was prevailing for a long period, during which Kosovo was under Serbian rule. This linguistic influence at its highest level in time period between 1970-1990, when Albanian language was used in police activities in Kosovo. In that time period most of the police officers were of the Albanian ethnicity and Kosovo had the status of autonomous province (1974-1990). English influence on police lexicon in Kosovo started in 1999 after liberation of Kosovo. From 1999 to 2008, English was used as the official language together with local languages Albanian and Serbian. This influence has not been limited only to police activities but it has spread widely into all fields of activities in Albanian language in Kosovo. Influence of English language in police lexicon is also evident in Albania, with words like: brifing (alb) - briefing (en), lidership (alb) - leadership (en), staf (alb.)- staff (en), task force (alb) - task force (en), etc. On the other hand Italian language is an influential language in police lexicon only in Albania due to historical, economic and cultural development. As a result, this is manifested by some basic words denoting police activities in Albania derived from Italian, like: komisiariati (alb) - commissariato (it), kavaleri (alb) - cavaleria (it), Policia e Shtetit (alb) - Polizia di Stato (it).
\end{abstract}

Keywords: Albanian, police lexicon, influence, Italian, English, Serbian.

Газірі Шемсі. Уплив іноземних мов на поліційний лексикон албанської мови.

Анотація. У цьому дослідженні ми спробували докладно пояснити вплив іноземних мов на поліцейський лексикон албанською мовою, 3 особливим акцентом на вплив сербської та англійської мов у Косово, а також вплив італійської та англійської мов в Албанії. Вплив сербської мови лише на поліцейський лексикон в Косово був створений внаслідок історичних обставин розвитку діяльності поліції за певних умов. Вплив сербської мови на поліцейський лексикон на албанській мові в Косово переважав протягом тривалого періоду, протягом якого Косово було під владою Сербії. Цей лінгвістичний вплив на найвищому рівні був у період між 1970-1990 рр., Коли албанська мова використовувалась у поліцейській діяльності в Косово. У той період більшість поліцейських були албанцями, а Косово мало статус автономної провінції (1974-1990). Вплив англійської мови на поліцейський лексикон у Косово розпочався у 1999 році після звільнення Косова. 31999 по 2008 рік англійська використовувалася як офіційна мова

(C) Haziri, Shemsi, 2020.

This is an Open Access article distributed under the terms and conditions of the Creative Commons Attribution 4.0 International Licence (https://creativecommons.org/licenses/by/4.0/).

East European Journal of Psycholinguistics, 7(2), 56-65. https://doi.org/10.29038/eejpl.2020.7.2.haz 
разом із місцевими мовами албанською та сербською. Цей вплив не обмежувався лише мовою поліції, він поширився на всі сфери діяльності албанською мовою в Косово. Вплив англійської мови в поліцейському лексиконі також видно в Албанії, наприклад, такі слова: brifing (alb) - брифінг (en), lidership (alb) - керівництво (en), staf (alb.) - персонал (en), робоча група (alb) - робоча група (en) тощо. 3 іншого боку, італійська мова $є$ впливовою мовою в поліцейському лексиконі лише в Албанії завдяки історичному, економічному та культурному розвитку. Як результат, це проявляється деякими релевантними словами, що позначають діяльність поліції в Албанії, які походять від італійської, наприклад: komisiariati (alb) - commissariato (it), kavaleri (alb) - cavaleria (it), Policia e Shtetit (alb) Polizia di Stato (it).

Ключові слова: албанська мова, полічійний лексикон, вплив, італійська мова, англійська мова, сербська мова.

\section{Introduction.}

\subsection{Theoretical Background}

During the historical development of police lexicon in Albanian language in Kosovo we observe that there has been continuous influence by foreign languages, like in all other areas of the society in development. Foreign languages with the highest extent of influence on police lexicon were as following: Serbian, in time period from 1970 to 1999, and English in post war Kosovo, 1999-2019, which played the leading role in all areas of society in Kosovo and in particular in the field of security. In Albania, we distinguish Italian as the most influential foreign language in period from 1920 to 1944. From 1945 to 1990 Russian had been the most influential language in Albania, whereas later on English and Italian language took the leading role. From 1990, after the collapse of communist system and the start of political pluralism in Albania, Italian regained its primary influential role, or in some cases, secondary, after English (Muceku, 2017). The influence of English has increased mainly in the last two decades when many words of English origin started to be used overwhelmingly due to global integration processes. This fact was highlighted by the researcher in the field of military terminology and the author of Albanian military dictionaries, Çipuri (2005, p. 250-263). Çipuri notes that loaning of English military terms, especially in the period of NATO influence, was done improperly, with the tendency of increasing the number of English loan words, "even of other neo-Latinisms through English, as for example: brifing (alb) - briefing (en), lidership (alb) - leadership (en), kamping (alb) - camping (en), menaxhim (alb) - managing (en), menaxher (alb) - manager (en), staf (alb) - staff (en), implementoj (alb) - implement (en), etc. (ibidem). Loaning of police terms in Albanian language in Albania and Kosovo in different time periods has led to the existence of different but synonymous words in the same language in two countries, Albania and Kosovo, as for example: komesariat (Albania) - stacion policor (Kosovo) for Police Station; Policia e Shtetit (Al) - Policia e Kosovës (Ks) for Police; kryekomisar (Al) - kapiten (Ks) for Captain; drejtues (Al) - major (Ks) for Major; komisar (Al) - toger (Ks) for Lieutenant, nënkomisar (Al) - rreshter $(K s)$ for Sergeant, etc. (Haziri, 2018a). The linguist Pasho (2017, p. 14) notes that in such cases of synonymous terms the principle one term - one concept and vice 
versa does not apply. However, the phenomenon of synonymous terminology in the same language between Kosovo and Albania occurred because of historic circumstances in ethnic territories inhabited by Albanian population, and also the influences of different governing systems in both countries. Despite that, in general, synonymy plays an important role in enriching Albanian language (Haziri, 2018b). Taking into consideration a relatively small number of studies of this kind in Albanian language, we have used most of the available sources regarding the topic of police lexicon in Albanian language. However, several foreign authors with works relevant to this study have also been taken into consideration. In this respect, we distinguish the following authors whose works made a significant contribution to the discussed topic (ASHSH, 1989; 2005; Bajçinca, 2016; Bogdanović, 2002; Pllana, 2017; Çipuri, 2005; Leksikologjia ... ; Duro, 2001; Muceku, 2017; Murati, 2016; Munishi, 2015; Nuhiu, 2013; Pasho, 2017; Zmijarević, 2007).

\section{Method}

In realization of this study, two methods have been used: comparative method and selection method. The comparative method has been used with the above mentioned literature and the comparison has been made between various terms in foreign languages (English, Serbian, and Italian) and Albanian police lexicon influenced by them. The selection method in this work has been used to identify specific studies and works which have served as the bases for identifying influences on Albanian police lexicon. In this way, it has been possible to collect the necessary data of the police lexicon from written documents in Kosovo and Albania (https://www.asp.gov.al; https://www.kosovopolice.com; http://www.poliziadistato.it).

\section{Results and Discussion}

\subsection{English Influence on Albanian Police Lexicon in Kosovo}

In Kosovo, similarly to other countries in the world during the globalization processes, the Anglicism's have entered and influenced the Albanian lexicon through different factors, with most important of them being administration of Kosovo by UNMIK Mission, which lasted for almost one decade. During this time period, 1999-2008, English was used as the official language together with local languages Albanian and Serbian. (Munishi, 2015, Haziri, 2015). According to Nuhiu (2013, p. 91) "the process of adjustment during the first and second phase usually does not last long, because as soon as a foreign word enters in a new language, the adjustment phase starts and continues until full integration or assimilation". Even nowadays, approximately one decade since Kosovo declared its independence, English continues to be the most influential language in the field of security, including police. This is due to the fact that most of the official documents, including those in the field of police activities, are compiled with the support of the authorities of the USA, Great Britain, EU international missions, OSCE, which directly leads to Anglicism's entering into Albanian language. V. Nuhiu (2013, p. 123) notes the fact that in Kosovo due to the long post war international administration and presence of international missions with English 
being their official language, loaning of Anglicism's became a widespread and uncontrolled phenomenon: It is evident that after the end of war in Kosovo a great number of English loan words entered in Albanian language. After the arrival of international governmental and non-governmental organizations and changes in the social system, it was impossible to analyze and control foreign words. Most of the Anglicism's were unnecessarily loaned due to the high number of those words entering the language in a very short time period. In addition to this, linguistic authorities of the country were not ready to treat loan words properly (ibidem). The influence of Anglicism's in police lexicon is evident in every official document of Kosovo Police, available in three languages, Albanian, Serbian and English. The practice of having translated versions of official documents started initially after the war in Kosovo, during UNMIK administration, and it continued even after declaration of Kosovo independence.

\subsection{Serbian Influence on Albanian Police Lexicon in Kosovo}

The influence of Serbian language on police lexicon in Albanian language in Kosovo was prevailing for a long period, during which Kosovo was under Serbian rule. This influence at its highest level in time period between1970-1990, when Albanian language was used in police activities in Kosovo. In that time period most of the police officers were of the Albanian ethnicity and Kosovo had the status of autonomous province (1974-1990). In 1971, in Vushtrri, in Kosovo, "High School on Internal Affairs" started to function in two official languages, Serbo-Croatian and Albanian, where young police cadets were trained to become police officers During the time Kosovo was an autonomous province the following documents, related to the work of police, were published in Albanian language: Constitution of the Autonomous Province of Kosovo (1974), Regulation in Internal Affairs (1975), Law on Internal Affairs (1981). Also, exercises of police duties in Kosovo were carried out using Albanian language. In his work, Disa probleme të shqipes në ligjet e Kosovës (Several Problems of Albanian Language in Laws in Kosovo), Bajçinca notes numerous problems within legal texts, which in many occasions were translated unprofessionally and with the influence of Serbian language: "The first issue is the terminology used in legal texts. Terms used in laws, in my opinion, since they were published in Pristina, are translations from Serbian language and there are a lot of terms which are new words used for the first time and they do not fit to the nature of Albanian language. In this context I will give an example of the word kryes (alb) - offender of a crime, instead of autor (al) - author, a word which is used in other fields as well, like construction, production... " (Bajçinca 2016, p. 293). Murati (2016: 487-494) gives examples of Serbian and Macedonian influence, like: "në lojën ftohtë-nxehtë"(alb) - "toplo-hladno" (Slavic); in Albanian "ngrirë-shkrirë" (alb) - frozen-melted; "fiton në peshë (alb)" - "dobija vo tezina" (Slavic). Therefore, it is clear that influences in lexicon were present in all fields of knowledge, like judiciary, police, society, culture, etc. During the above-mentioned period police lexicon in Kosovo was influenced to quite a high extent by Serbian language, since all documents of police scope were translated from Serbo-Croatian language, as an important language not only in Ex-Yugoslavia but even further. There are numerous examples of loan translations of police ranks 
during the time period between 1976-1991, like: mladi inspector (srb) - inspektor $i$ ri (alb), glavni inspektor (srb) - inspektor kryesor (alb), etc. (Bogdanović, 2002). The influence of Serbian language, or Serbo-Croatian which was the official name of the language at that time, on Albanian language was present also in the names of positions in police (called milicia at that time), like: komandir stanice milicije (srb) - komandant $i$ stacionit të policisë (alb); sektor za sigurnost (srb) - sektori $i$ sigurisë (alb); jedinica za vlakopratnju (srb) - njësia e trenit (alb), etc. (Zmijarević: 2007, p. 217). Some of the police terms like: komandant i stacionit, sektor policor, njësi policore, are still being used in the organizational structure of Kosovo Police.

\subsection{English Influence on Albanian Police Lexicon in Albania}

In Albania, similarly to Kosovo, the influence of English language has been taking a dominant role. Taking into account the processes of European integrations, as well as the membership of Albania in NATO alliance, in the last decade English language has become the most dominant and influential language in the field of security in Albania. In the last two decades Albanian State Police has been cooperating with international partners like: PAMECA, ICITAP, OSCE, Swedish Program of Community Policing and Police forces of EU countries. Communication with them is performed in English, which then has an impact on police lexicon. There are many examples of terms directly influenced by English, as for example: investigim (alb) - investigation; vetingu (alb) - vetting, implementim (alb) - implementation, etc. Munishi (2015: 30), notes that Albanian language has entered the globalization era and it has been loaning words of different social fields, as for example: menaxhim (alb) - managing, menaxhment (alb) - management, privatizim (alb) - privatization, partner (alb) - partner, partnership (alb) - partnership, auditim (alb) - auditing, ndërtim i kapaciteteve (alb) - building capacities, resurse humane (alb) - human resources, qëndrueshmëri buxhetore (alb) - budget stability, politika publike (alb) - public policies, administrim biznesi (alb) - business administration, etc. The linguist Gani Pllana (2017) performed a research in regards to adaptation of terminology of Albanian language to its overall lexicon, and in particular of technical terminology, which we took as a basis during this study. On the other hand the linguist Agron Duro (2011) conducted a research in the field of the theoretical system of terminology of Albanian language, which was also useful for this study. Besides these two authors we also consulted other relevant Albanian authors of similar fields of study (ibidem).

\subsection{Italian Influence on Albanian Police Lexicon in Albania}

Influence of Italian language on Albanian police lexicon in Albania has been since the time after the declaration of independence of Albania in 1912. In that time the National Guard of Albania was called "Kavaleri" (Italian: Cavaleria) - meaning Cavalry. During the time when Albania was a monarch state, under the reign of King Zog (1928-1939), numerous Italian loan words were part of Albanian police lexicon, like: Arma e Karabinierisë, karabinieri, 
Trupi i Armatosur i Policisë së Shqipërisë, Drejtoria Qendrore e Policisë së Shqipërisë, postat e kufirit, drejtori i Drejtorisë Qendrore të Policisë, këshilltari $i$ përhershëm, nëkuestori, funksionar i sigurimit publik, agjent $i$ sigurimit, Trupi $i$ Gjindarmërisë Mbretnore (TGJM), Arma e Karibinierisë Mbretnore, komandant i Armës së Gjindarmërisë, etc. During the post second world war period, in communist Albania, the Italian influence decreased, whereas there was an increase of influence by Russian language. Since 1990, besides English, Italian has become again the most influential language in all areas of society in Albania, especially in the field of security. Even the name of the police force of Albania "Policia e Shtetit" - State Police was loaned directly from Italian language Polizia di Stato. This can be checked by visiting the official website of Italian Police force: http://www.poliziadistato.it. Also the term Commissariato (it) - Komisariat (alb), meaning police station, is a direct loan from Italian. In the law on State Police (2014) there are numerous loan words from Italian language, with the influence including their stress and pronunciation, like for example: impianto stazionario (it) - impiant stacionar (alb), meaning stationary equipment. (Haziri, 2015).

In Kosovo there was the influence and dominance of Serbian / Serbo-Croatian language in the time period of 1970-1990, which used to be an important language in Ex-Yugoslavia and in the region of South-East Europe. We will mention several translations of names and functions in police lexicon in the time period between 1976-1991: mladi inspektor (srb) - inspektor i ri (alb), mladi milicionar (srb) milicioner $i$ ri (alb), milicionar (srb) - milicioner (alb), stari milicionar (srb) milicioner $i$ vjetër (alb), visi milicionar (srb) - milicioner i lartë (alb), visi inspektor (srb) - inspektor i lartë (alb), glavni inspektor (srb) - inspektor kryesor $(a l b)$, etc. The names of all positions in police (milici), like: načelnik služba javne sigurnosti (srb) - kryeshef $i$ shërbimit të sigurimit publik (alb), komandir stanice milicije (srb) - komandant i stacionit të policisë (alb), sektor za krim (srb) - sektori $i$ krimeve (alb), sektor za sigurnost (srb) - sektori i sigurisë (alb), etc. Furthermore, some positions like: komandant i stacionit, sektor policor, njësi policore, are still in use in the current organizational structure of Kosovo Police. English influence on Albanian police lexicon in Kosovo in the time period between 1999-2019 is evident due to its wide usage in all areas of Kosovo society. We can distinguish the influence through word for word translation of some terms, like: police officer (en) - zyrtar policor (alb), local police station (en) - stacionet policore lokale (alb); civilian staff (en) - stafi civil (alb), etc. There are also examples of adaptation into Albanian of original loan words, as for example: supplementary (en) - suplementar (alb); proportionality (en) - proporcionaliteti (alb), performance (en) performanca (alb), implement (en) - implementim (alb), etc.

In the tables below there are shown names of police ranks and positions in Albanian language in Kosovo, which differ due to different influences on police lexicon during different time periods. 
Table 1.

Police Rank Names in Kosovo in Different Time Periods

\begin{tabular}{ccc}
\hline 1970-1990 & 1999-2008 & 2008-2020 \\
\hline Milicioner i ri & Polic (pjesëtar) i SHPK-së & Polic i ri \\
Milicioner & Polic (pjesëtar) i SHPK-së & Polic \\
Milicioner i klasës së & & \\
parë & & \\
Milicioner i vjetër & Polic (pjesëtar) i SHPK-së & Polic i lartë \\
Milicioner i vjetër i & & \\
klasës I & & \\
Milicioner i lartë & Rreshter & Rreshter \\
Inspektor i ri & Toger & Toger \\
Inspektor & Kapiten & Kapiten \\
Inspektor i vjetër & Major & Major \\
Inspektor i pavarur & Nënkolonel & Nënkolonel \\
Inspektor i lartë & Kolonel & Kolonel \\
& Asistent i Komesarit - & Ndihmësdrejtor i \\
Inspektor i lartë i & gjeneralmajor & Përgjithshëm/Drejtor \\
klasës I & Zepartamenti \\
& Zv. Komesar - & Zv. Drejtor i Përgjithshëm \\
Inspektor Kryesor & Komesar - gjeneralkolonel & Drejtor i Përgjithshëm \\
\hline
\end{tabular}

Table 2.

Police Positions in Kosovo in Different Time Periods

\begin{tabular}{ccc}
\hline 1970-1990 & $\mathbf{1 9 9 9 - 2 0 0 8}$ & 2008-2020 \\
\hline Kryeshef i Drejtoratit të & Komandant Regjional i & Drejtor Rajonal i Policisë \\
Milicisë & Shërbimit Policor & \\
Postkomandant i & Komandant i Shërbimit & Komandant i Policisë \\
Milicisë & Policor & \\
Zëvendëspostkomandant & Zëvendëskomandant & Zëvendëskomandant \\
i Milicisë & i SHPK-së & i Policisë \\
Ndihmëspostkomandant & Shefi i Operativës së & Shef i Operativës së \\
i Milicisë & Stacionit të SHPK-së & Stacionit të Policisë \\
Sekretar Krahinor & Shef i Shtyllës së Parë & Ministër i Punëve \\
i Punëve të Brendshme & të UNMIK-ut & të Brendshme \\
Sekretar Krahinor & Komesar i Policisë & Drejtor i Përgjithshëm \\
i Punëve të Brendshme & së UNMIK-ut & i Policisë \\
Vrojtës i Milicisë & Pjesëtar patrullues i SHPK- & Zyrtar i Ekipit Reagues \\
& së & i Policisë \\
\hline
\end{tabular}

In the lexicon of Albanian Police Force (Policia e Shtetit) there are many words and terms of English origin, like: investigim (alb) - investigation (en); 
implementim (alb) - implementation (en), veting (alb) - vetting (en), efekt (alb) effect (en), etc. The influence of Italian language in police lexicon in Albania has early roots, because of the relationships between two nations during many centuries. We may distinguish some police terms which have been loaned directly from Italian, like: Kavaleria (it) - Kalorësia (alb), in the time of Vlora Government in 1913, Arma dei Carabinieri (it) - Arma e Karabinierisë (alb), aspirante (it) aspirant (alb), etc., in the time of monarchy, etc. Currently, we distinguish some terms like: Komesariat (from Italian commissariato), Policia e Shtetit (from Italian Polizia di Stato), inspector (Italian Ispettore), etc. The following are example of police lexicon comparisons between Kosovo and Albania:

Table 3.

Comparison of Police Ranks in Kosovo and Albania

\section{$\begin{array}{lll}\text { Ranks } & \text { Kosovo } & \text { Albania }\end{array}$}

1. Kadet policor

2. Polic i ri

2.1. Polic

2.2. Polic i lartë

3. Rreshter

4. Toger

5. Kapiten

6. Major

7. Nënkolonel

8.Kolonel
1. Kursant

2. Inspektor

3. Nënkomisar

4.Komisar

5.Kryekomisar

6.Drejtues

7.Drejtues i parë

8.Drejtues i lartë

8.1. Drejtor i Departamentit

8.2. Zv. Drejtor i Përgjithshëm

9. Drejtor i Përgjithshëm i Policisë së Kosovës

9. Drejtues madhor (Drejtor i

Përgjithshëm i Policisë së Shtetit)

Table 4.

Police Positions and Functions in Kosovo and Albania

Police

Positions

and

Functions

Kosovo

Albania

\section{Staf Civil}

Komandant i Stacionit Policor

Kryeshef i Inspektoratit Policor

të Kosovës
Punonjës administrativ

Shef i Komisariatit

Drejtor i Shërbimit për Çështje të

Brendshme dhe Ankesa 


$\begin{array}{cc}\text { Mbikëqyrës i Ekipit Reagues } & \begin{array}{c}\text { Shef i Seksionit të Patrullës së } \\ \text { Përgjithshme }\end{array} \\ \text { Komandant i Njësisë Rajonale } & \text { Shef i Komisariatit të Policisë } \\ \text { të Komunikacionit Rrugor } & \text { Rrugore } \\ \text { Hetues i Sektorit për Hetimin e } & \begin{array}{c}\text { Specialist i Sektorit për Hetimin e } \\ \text { Narkotikëve }\end{array} \\ \text { Narkotikëve dhe Trafiqeve } \\ \text { Hetues i Sektorit të Hetimeve }- & \begin{array}{c}\text { Specialist i Seksionit për Hetimin } \\ \text { Stacioni Policor }\end{array} \\ \text { e Krimeve - Komisariati i Policisë } \\ \text { Operator i Njësisë Speciale } & \text { Punonjës i Repartit të Forcave } \\ \text { Intervenuese - NJSI (FIT) } & \text { Speciale - RENEA } \\ \text { Hetues i Departamentit të } & \text { Specialist i Byrosë Kombëtare të } \\ \text { Hetimeve } & \text { Hetimit }\end{array}$

\section{Conclusion}

To sum up, in Kosovo, during the time period 1970-1999, Serbian language was the most influential language. We have presented numerous examples of loan translations of names and functions in police activities (milici) during the time period 1976-1991. Furthermore, some names of positions are still in use in the current organizational structure of Kosovo Police. The influence of English language in Kosovo during the time period 1999-2019 is evident because of its dominant role in all areas in Kosovo, including the area of security, part of which is Kosovo Police. The influence of Serbian language on Albanian language in Kosovo has come as a result of its official prestige of being the most dominant language (Serbo-Croatian) in ex-Yugoslavia and in the South-Eastern Europe. This was the case due to great industrial and economic development, education system, great success in sports activities, etc., during that time period (1970-1990). On the other hand, the influence of Italian language onto the vocabulary of State Police of Albania dates from the establishment of Albanian state and continues until nowadays thanks to close neighborly relationships for a long time between Albania and Italy. The influence of English language on police lexicon in Albanian language is obvious and evident in Albania and Kosovo, taking into consideration integration processes and the prestige of English language as a global language.

\section{References}

ASHSH. (1989). Studime për leksikun dhe formimin e fjalëve në gjuhën shqipe III. (1989). [Studies on Lexicon and Word Formation in Albanian Language III]. Tiranë.

ASHSH. (2005). Leksikografia shqipe - trashëgimi dhe perspective [Albanian Lexicography Heritage and Perspective]. Tiranë.

Haziri, S. (2015). Dallimet terminologjike në mes të Ligjit të Policisë së Kosovës dhe Ligjit të Policisë së Shtetit dhe ca prurje të reja, Albanologji, 6, 279-287.

Haziri, S. (2015), Shkëmbimi gjuhësor gjatë bisedave në Qendrat Komunikuese të Policisë së Kosovës, International Seminar of Albanian Language, 35, 505-516. Retrieved from: https://filologjia.uni-pr.edu/getattachment/Seminari/Seminari---Gjuhesi---Vellimi1.pdf.aspx 
Haziri, S. (2018a). Zhvillimi i leksikut policor në gjuhën shqipe në Kosovë, Studime Albanologjike 18, 191-201.

Haziri, S. (2018b), Sinonimet në leksikut policor Kosovë-Shqipëri, International Seminar for Albanian Language, Literature and Culture, 37, 345-359. Retrieved from: https://www.ceeol.com/search/article-detail?id=784343

Haziri, S., Munishi, Sh. (2018). Development of Police Terminology in Albanian Language in Kosovo and Albania, Advances in Language and Literary Studies, 9(6), 126. http://dx.doi.org/10.7575/aiac.alls.v.9n.6p.126

Bajçinca, I. (2016). Shqipja standarde dhe probleme rreth saj [Standard Albanian and Its Problems]. Pristina: Institute of Albanology. Association of Albanian Language.

Bogdanović, B. (2002). Dva veka policije u Srbiji [Two Centuries of Police in Serbia]. Belgrade.

Pllana, G. (2017). Formimi i terminologjive teknike shqipe mbi bazën e leksikut të përgjithshëm [Formation of Technical Terminology in Albanian Based on General Lexicon]. QSA. Tirana.

Çipuri, H. (2005). Termat dhe fjalorët terminologjikë ushtarakë në gjuhën shqipe [Terms and Military Terminology Dictionaries in Albanian]. Leksikologjia shqipe, trashëgimi dhe perspektivë. Tirana.

Duro, A. (2001). Terminologjia si system [Terminology as a System]. Tirana.

Islamaj, Sh. (1989). Roli i sinonimisë në pasurimin e gjuhës [Role of Synonymy in Language Enrichment]. ASHSH. Studime për leksikun dhe formimin e fjalëve në gjuhën shqipe III [Studies on Lexicon and Word Formation in Albanian III]. Tirana.

Muceku, A. (2017). Përparësitë e përdorimit të teknikave audio-vizive, të lidhura ngushtësisht me përvetësimin gjuhësor të gjuhëve të huaja në sistemin arsimor shqiptar sipas standardeve evropiane - rasti i italishtes [Advantages of Usage of Audio-Visual Techniques, Closely Linked to Learning of Foreign Languages in Albanian Education System Based on European Standards - Case of Italian], PhD Dissertation. Tirana.

Murati, Q. (2016). Për kulturën gjuhësore shqipe [Albanian Language Culture]. Pristina: Instituti Albanologjik i Prishtinës.

Munishi, Sh. (2015). Shqipja në epokën e globalizimit [Albanian Language in the Globalization Era]. Pristina: ZeroPrint.

Nuhiu, V. (2013). Ndikimi $i$ anglishtes në gjuhën shqipe [English Influence on Albanian Language]. Pristina.

Pasho, H. (2017). Probleme gjuhësore të terminologjisë në gjuhën shqipe [Language Terminology Problems in Albanian]. Tirana: Akademia e Studimeve Albanologjike.

Proko, V. (2012). Leksiku terminologjik i agronomisë në gjuhën shqipe [Agronomy Lexicon in Albanian Language]. QSA. Tirana.

Zmijarević, N. (2007). Policija u Hrvatskoj od 1941 do 2001 [Police in Croatia from 1941 to 2001]. Zagreb: Ministarstvo unutarnjih poslova, Policijska akademija.

\section{Sources}

https://www.asp.gov.al

https://www.kosovopolice.com

https://pt.wikipedia.org/wiki/Pol\%C3\%ADcia_do_Estado_(Itália)

http://www.poliziadistato.it 